\title{
STONE V. PHILBROOK: ANOTHER WORD \\ ON THREE-JUDGE COURTS AND DECLARATORY JUDGMENTS
}

The federal three-judge court statutes ${ }^{1}$ come into play when injunctive relief from the enforcement of a state or federal statute or a state regulation is sought on federal constitutional grounds. The ostensible purpose of these statutes is to protect state and federal programs from paralysis by the action of "one little federal judge." Courts, however, have construed these statutes inconsistently: some decisions have denied the protection of the statutes to those they were intended to aid, while others have extended protection to those they were not intended to aid. ${ }^{3}$ Two outstanding features of the statutes have produced these results. First, in the cases in which the statutes are applicable, a court of three judges must be convened whether or not the state or federal defendant whose program is challenged requests it. Because these statutes, as presently construed, are jurisdictional in nature, a single judge is always incompetent to decide a

128 U.S.C. $\S \S 1253,2281-84$ (1970). The texts of the two sections most important for this Comment follow:

28 U.S.C. \$ 2281:

An interlocutory or permanent injunction restraining the enforcement, operation or execution of any state statute by restraining the action of any officer of such State in the enforcement or execution of such statute or of an order made by an administrative board or commission acting under State statutes, shall not be granted by any district court or judge thereof upon the ground of the unconstitutionality of such statute unless the application therefor is heard and determined by a district court of three judges under section 2284 of this title.

28 U.S.C. $\S 1253$ :

Except as otherwise provided by law, any party may appeal to the Supreme Court from an order granting or denying, after notice and hearing, an interlocutory or permanent injunction in any civil action, suit or proceeding required by any Act of Congress to be heard and determined by a district court of three judges.

28 U.S.C. $\S 2284$ prescribes the procedural steps to be taken upon receipt of a complaint requiring a three-judge court.

245 CoNG. REC. 7256 (1910) (remarks of Senator Overman).

${ }^{3}$ See generally P. Bator, P. Mishkin, D. Shapiro \& H. Wechsler, Hart and Wechsler's The Federal Courts and the Federal System 962-75 (2d ed. 1973) [hereinafter cited as Hart and WechsLer]; Currie, The Three-Judge District Court in Constitutional Litigation, 32 U. CHI. L. REV. 1 (1964). 
case which must be determined by three judges. ${ }^{4}$ Second, review of orders of three-judge courts granting or denying injunctions is by mandatory appeal to the Supreme Court, without intermediate review. These two features have motivated the courts to narrow the range of cases to which the statutes apply and the range of actions within a case that must be taken by a court of three judges. ${ }^{5}$

A stable body of law has not yet evolved. Questions concerning when a three-judge court must be convened and what actions a single judge may take are still unsettled. In Stone v. Philbrook ${ }^{6}$ the Second Circuit, speaking through Judge Henry Friendly, ${ }^{7}$ considered the limits of single-judge jurisdiction where both declaratory and injunctive remedies are sought. The court concluded that a single judge has the jurisdiction to decide the case as long as he grants only declaratory relief and that the single judge has power to abstain on remand.

\section{STONE V. PHILBROOK}

In Stone $e^{8}$ a Vermont recipient of General Assistance challenged the validity under the Federal Constitution of the regulations of Vermont's Department of Social Welfare in a suit against

${ }^{4}$ E.g., Ex parte Metropolitan Water Co., 220 U.S. 539 (1911) (three judges needed to deny injunction as well as to grant it). This case states that the three-judge statutes are jurisdictional. $I d$. at 545 .

5 Five ways in which three-judge court jurisdiction and associated appellate jurisdiction of the Supreme Court have been limited are: (1) narrowing the definition of attack upon a state statute, e.g., Phillips v. United States, 312 U.S. 246 (1941); Rorick v. Board of Comm'rs, 307 U.S. 208, 212 (1939) (statute must be of statewide application before requiring three judges); (2) narrowing the definition of unconstitutionality which will support the call for a three-judge court, Swift \& Co. v. Wickham, 382 U.S. 111 (1965) (supremacy clause claims do not require three-judge courts); (3) dropping the requirement of three judges in cases when unconstitutionality is clear under prior decisions, Bailey v. Patterson, 369 U.S. 31 (1962) (a de jure segregation case; perhaps a procedural anomaly); (4) limiting the types of orders appealable to the Supreme Court, e.g., Gonzalez v. Automatic Employees Credit Union, 419 U.S. 90 (1974) (dismissal of complaint for lack of standing by three-judge court must be appealed to court of appeals); Schackman v. Arnebergh, 387 U.S. 427 (1967) (per curiam) (refusal to convene three-judge court appealable to court of appeals) (note that if the refusal is wrong, a subsequent dismissal is effectively a denial of an injunction in a case required to be heard by three judges); and (5) limiting the types of relief which can be granted only by three-judge courts, see notes 18-30 infra \& accompanying text for cases distinguishing, for the purpose of the three-judge court statutes, claims for declaratory and injunctive relief, an issue in the case under discussion in this Comment.

6528 F.2d 1084 (2d Cir. 1975).

7 Judge Friendly's opinions on other issues of federal court jurisdiction have often proved influential. See, e.g., Eisen v. Eastman, 421 F.2d 560 (2d Cir. 1969); T.B. Harms Co. v. Eliscu, 339 F.2d 823 (2d Cir. 1964).

${ }^{8} 528$ F.2d 1084 (2d Cir. 1975). 
the Commissioner of the Department. He attacked the regulations as unconstitutional for failing to provide for a "trial-type" hearing before termination of assistance. ${ }^{9}$ In his complaint plaintiff Stone requested both declaratory and injunctive relief. ${ }^{10}$

Stone moved for certification of the suit as a class action and for summary judgment without specifying the type of relief he sought under the motion. After considering the Commissioner's affidavits in opposition, the single district judge granted both motions:

[T] ]he plaintiff's motion for class action certification is granted with respect to those receiving General Assistance three or more times per month. The plaintiff's motion for summary judgment is granted as the Court finds and declares the State's policy of denying evidentiary hearings to regular recipients of General Assistance, as defined in this opinion, to be unconstitutional. ${ }^{11}$

After the judgment, the defendant raised for the first time the three-judge requirement of section 2281 of Title 28 and moved that the district judge vacate his order for lack of jurisdiction. The judge denied the motion without explanation. ${ }^{12}$ The defendant appealed to the court of appeals both from the district judge's finding that he had jurisdiction and from the order declaring that the regulations as applied to regular recipients of General Assistance were unconstitutional.

On the jurisdictional issue, the court of appeals held both that it had jurisdiction to hear the appeal from the single-judge district court and that the single judge had jurisdiction to decide the case as he did. The court based its holding on a finding that "what the district court entered was a declaratory judgment, not an injunction."13

On the merits the court then concluded that the regulations were constitutional. ${ }^{14}$ Plaintiff also raised before the court of

${ }^{9} I d$. at 1085 . The regulations required "new" applications for General Assistance each week, including evidence of 20 hours' effort to find full or part-time employment.

${ }^{10} \mathrm{Id}$. at 1086. Stone was an intervenor; the suit of the original plaintiff was dismissed. It is not clear what relief the original plaintiff in the suit had sought; even if he had sought only declaratory relief, the suit became one for injunctive relief when Stone was allowed to intervene.

${ }^{11}$ Id. at $1087-88$.

${ }^{12} I d$. at 1088.

${ }^{13} I d$.

${ }^{14} I d$. at 1091. 
appeals, however, the question whether the Commissioner exceeded his statutory authority by issuing these regulations. Despite the fact that this problem was raised for the first time on appeal, Judge Friendly held that it had "sufficient merit" to be considered on remand. ${ }^{15}$ After a brief review of the problem, however, Judge Friendly concluded that it was a "delicate question of state law" best considered by Vermont's own courts. ${ }^{16}$ The court of appeals therefore vacated the order granting class action status and summary judgment to the plaintiff and ordered the district judge to abstain and to retain jurisdiction of the case while the parties sought determination of the state law question in the state courts. ${ }^{17}$

\footnotetext{
${ }^{15} \mathrm{Id}$.

${ }^{16}$ Id. at 1094.

${ }^{17}$ Id.
}

In abstaining, the court relied on Railroad Comm'n v. Pullman Co., 312 U.S. 496 (1941). Pullman indicates that abstention-retaining jurisdiction of the federal questions in a case while directing the parties to seek a determination of state law questions in state court-is appropriate in cases in which there is both an unclear question of state law and a "substantial constitutional issue" which might be avoided by decision of the state law issue. 312 U.S. at 498-500. See Field, Abstention in Constitutional Cases: The Scope of the Pullman Abstention Doctrine, 122 U. PA. L. Rev. 1071, 1088 (1974). The two basic policies served by abstention are (1) avoiding unnecessary constitutional decisions, and (2) avoiding the possible disruption of state programs by federal error in deciding a state law issue. See id. 1083-1101.

In Stone, however, the constitutional question was not overly difficult. In fact, the court of appeals dealt with it rather summarily, holding the regulations clearly constitutional. Abstention to avoid an unnecessary constitutional decision is not appropriate if the constitutional question is neither difficult nor unsettling. See Wisconsin v. Constantineau, 400 U.S. 433 (1971); Field, supra, at 1096-1101.

If there were other reasons to retain jurisdiction of the case, the alternate policy of abstention, avoiding disruption of state programs, might favor leaving the question of state law to the state courts, especially after the court of appeals found the state law question genuinely difficult and unsettled.

In Stone, however, the court not only indicated that the constitutional question was easy but also held that if the regulations were authorized by state statute, they were constitutional, thereby leaving no constitutional issue to avoid. In abstaining, the court relied on County of Allegheny v. Frank Mashuda Co., 360 U.S. 185 (1959), an eminent domain case in federal court under diversity jurisdiction that involved the issue of abstention when there was no constitutional question to avoid. The Court held that abstention in such a case "can be justified ... only in the exceptional circumstances where the order to the parties to repair to the state court would clearly serve an important countervailing interest." 360 U.S. at 188-89. Unable to find such an interest in Mashuda, the Court affirmed the court of appeals' reversal of the district court's decision to abstain.

The citation of Mashuda in Stone is particularly noteworthy because the court does not mention Louisiana Power \& Light Co. v. City of Thibodaux, 360 U.S. 25 (1959), another eminent domain case under diversity jurisdiction, decided the same day as Mashuda, in which there was no constitutional question, but in which the Supreme Court permitted the district court to abstain. Thibodaux has been read to allow abstention in cases in which only one of the two interests protected by Pullman abstention, 


\section{Declaratory Judgments and InJunctions}

\section{A. The Distinction Between Declaratory and Injunctive Relief in Three-Judge Court Cases}

The jurisdictional question in Stone did not center on whether the court of appeals could hear the case. Even if the single judge did not have jurisdiction to enter his order, the court of appeals had the power on review to order the judge to request a three-judge court. ${ }^{18}$ To reach the merits of the district court decision, however, the court of appeals had to hold also that the single district judge acted within his jurisdiction in granting Stone's motion for summary judgment. ${ }^{19}$ In holding that a single judge has jurisdiction to enter a declaratory judgment in a case in which the plaintiff seeks both declaratory and injunctive relief, the court of appeals went beyond earlier declaratory judgment cases.

avoiding the disruption of a state program, is implicated. E.g., United Servs. Life Ins. Co. v. Delaney, 328 F.2d 483 (5th Cir.), cert. denied, 377 U.S. 935 (1964); cf. Phillips, Nizer, Benjamin, Krim \& Ballon v. Rosenstiel, 490 F.2d 509, 515-16 (2d Cir. 1973) (Friendly, J.). Such a reading, however, would undermine Pullman. Since Thibodaux, the Supreme Court has indicated that abstention under Pullman requires a constitutional question. E.g., Baggett v. Bullitt, 377 U.S. 360, 375-78 (1964). Thibodaux has been interpreted as a separate category of abstention requiring factors in addition to the possibility of avoiding disruption of a state program. See Field, supra, at 1148-53.

The court's abstaining in Stone, then, after reaching the constitutional question, could be explained under a broad reading of Pullman (perhaps taking Thibodatux and Mashuda as modifying Pullman) which would allow abstention without a constitutional question, or under a reading of Mashuda and Thibodaux as a separate category of abstention. By the latter interpretation the court in Stone held that avoiding disruption of a state welfare program and, in particular, avoiding interference with a state's regulating the overall funding level of such a program, represent the kind of "important countervailing interest" which justifies abstention without a constitutional question. See Field, supra, at 1096-1101, 1148-53.

In addition, once the court of appeals in Stone reached the federal question that gave the court jurisdiction and decided it adversely to the plaintiff, it became appropriate for the court to use its discretion to decline pendent jurisdiction of the state law question under United Mine Workers v. Gibbs, 383 U.S. 715, 726-27 (1966): The court had disposed of the federal question quickly, the case had not moved to trial but was decided at the summary judgment stage, the state law question would involve a difficult issue and perhaps lengthy proceedings, and the plaintiff had failed to argue the state law question until the court of appeals. In fact, because the court ordered abstention only after reaching the federal question, unless advantages to the federal injunctive or declaratory relief procedures existed which were not identified in the case, dismissal of the pendent claim without prejudice, which would allow the plaintiff to bring a single suit in state court to decide the state law claim, would have been the preferable course.

${ }^{18}$ Idlewild Bon Voyage Liquor Corp. v. Epstein, 370 U.S. 713, 715-16 (1962); Schackman v. Arnebergh, 387 U.S. 427 (1967); see Currie, supra note 3, at 66-76.

1" 528 F.2d at 1089. Otherwise the court of appeals should have vacated and remanded for consideration by a three-judge court. 
The court correctly traced the doctrine that three judges need not hear.a suit for declaratory relief to its origins in Kennedy $v$. Mendoza-Martinez. ${ }^{20}$ In that case the plaintiff sought only declaratory relief throughout the entire case. Although the plaintiff included a prayer for injunctive relief in one amended complaint, "neither the parties nor the judge at any relevant time regarded the action as one in which injunctive relief was material to the disposition of the case."21

Mendoza-Martinez explicitly stopped short, however, of holding that no request for declaratory relief alone was to be considered the same as a request for an injunction, and in fact implied that in some cases the two should be treated identically:

Whether an action solely for declaratory relief would under all circumstances be inappropriate for consideration by a three-judge court we need not now decide, for it is clear that in the present case the congressional policy underlying the statute was not frustrated by trial before a single judge. The legislative history of $\S 2282$ and of its complement, $\S 2281$, requiring three judges to hear injunctive suits directed against federal and state legislation, respectively, indicates that these sections were enacted to prevent a single federal judge from being able to paralyze totally the operation of an entire regulatory scheme, either state or federal, by issuance of a broad injunctive order. ...

The present action, which in form was for declaratory relief and which in its agreed substance did not contemplate injunctive relief, involves none of the dangers to which Congress was addressing itself. The relief sought and the order entered affected an Act of Congress in a totally noncoercive fashion. There was no interdiction of the operation at large of the statute. It .was declared unconstitutional, but without even an injunctive sanction against the application of the statute by the Government to Méndoza-Martinez. Pending review in the Court of Appeals and in this Court, the Government has been free to continue to apply the statute. ${ }^{22}$

\footnotetext{
20372 U.S. 144 (1963).

${ }^{21}$ Id. at 154 .

${ }^{22}$ Id. at 154-55 (footnote omitted).
} 
In Rockefeller v. Catholic Medical Center, ${ }^{23}$ the Supreme Court used language extending Mendoza-Martinez to declaratory relief generally. On its facts, Rockefeller should have been decided on other principles clearly enunciated in earlier cases $;{ }^{24}$ nonetheless, it became the first precedent for the proposition that no declaratory judgments are equivalent to injunctions for the purposes of the three-judge court statutes. In Rockefeller and subsequent cases up to Steffel $v$. Thompson, ${ }^{25}$ on which the Stone court relied, however, the question was whether the Supreme Court or the court of appeals had appellate jurisdiction over a three-judge court's order granting declaratory relief. ${ }^{26}$ The jurisdiction of

23397 U.S. 820 (1970) (per curiam).

${ }^{24}$ The plaintiff in Catholic Medical Center v. Rockefeller, 305 F. Supp. 1256 (interim memorandum), memorandum granting declaratory relief issued, $305 \mathrm{~F}$. Supp. 1268 (E.D.N.Y. 1969), vacated and remanded with instructions to enter a new order for review in the court of appeals, 397 U.S. 820 (1970), sought a preliminary injunction against, $305 \mathrm{~F}$. Supp. at 1260, and declaratory relief from, a New York statute on the grounds that it violated Title XIX of the Social Security Act and the fourteenth amendment. A threejudge court, convened because of the latter claim, addressed the supremacy clause claim (Social Security Act overrides state statute) first, holding the state law inconsistent with the federal and therefore invalid. Id. at 1271 . The court issued declaratory relief on this ground, denied the injunction, and stated that it was unnecessary to reach the constitutional issue. Id. The deciding factor barring direct Supreme Court review should have been that the defendant appealed a decision based on only statutory or supremacy clause grounds. Such decisions do not entitle a litigant to direct review. Swift \& Co. v. Wickham, 382 U.S. 111 (1965). Perhaps Justice Douglas recognized this when he concurred only in the result, 397 U.S. at 820 .

It is unfortunate that the Supreme Court announced this apparent distinction between all declaratory judgments and all injunctions in a per curiam memorandum in a case which could have been decided the same way on another, well-established ground.

${ }^{25} 415$ U.S. 452 (1974).

${ }^{26}$ The subsequent cases on which the Stone court relied are Mitchell v. Donovan, 398 U.S. 427 (1970) (per curiam), Gunn v. University Comm., 399 U.S. 383 (1970), and Thoms v. Heffernan, 473 F.2d 478 (2d Cir. 1973), vacated and remanded on other grounds, 418 U.S. 908 (1974).

In Mitchell the Supreme Court found that plaintiff had been denied declaratory relief only (a request for an injunction had been properly dismissed as moot). Therefore, no request for an injunction had been granted or denied, and appeal lay solely to the court of appeals.

In Gunn a three-judge district court, convened at plaintiff's request to consider his complaint that the Texas "disturbing the peace" statute was unconstitutional, held that plaintiff was entitled to the declaratory and injunctive relief he sought. The court, however, stayed its mandate until the end of the next session of the Texas legislature to give the state an opportunity to pass a new statute, and retained jurisdiction. 399 U.S. at 386. The Supreme Court dismissed the state's direct appeal for lack of jurisdiction, concluding that an injunction had not been ordered (and that plaintiff had not appealed the denial), id. at $388-90$, but indicating in addition that the district court had not issued any final order, and that no appeal was available in any court until the district court took reviewable "formal action." Id. at 380 n.6.

Only Justice White, in his concurring opinion joined by Justice Brennan, clearly stated that the district court's opinion should be treated "as having the operative effect 
the district court was not at issue in any of these cases. Three judges had been convened, and the district court therefore would have had jurisdiction to grant an injunction. In Stone, however, the question was whether a single judge, faced with a request for both declaratory and injunctive relief, has jurisdiction to grant only the former.

The Stone court relied upon Steffel v. Thompson ${ }^{27}$ for its holding that a single judge can grant declaratory relief. In Steffel plaintiff challenged a Texas criminal trespass statute, and a single judge denied both declaratory and injunctive relief. ${ }^{28} \mathrm{On}$ his appeal to the Fifth Circuit, however, plaintiff abandoned his claim for an injunction and appealed only from the denial of declaratory relief. ${ }^{29}$ Reviewing the court of appeals' affirmance, the Supreme Court stated:

Since the complaint had originally sought to enjoin enforcement of the state statute on grounds of unconstitutionality, a three-judge district court should have been convened. ... A three-judge court . . . is normally required even if the decision is to dismiss under Younger-Samuels principles, since an exercise of discretion will usually be necessary .... . But since petitioner's request for injunctive relief was abandoned on appeal ... and only a request for declaratory relief remained, the Court of Appeals did not err in exercising jurisdiction over the appeal. ${ }^{30}$

of a declaratory judgment." Id. at 391 (White, J., concurring).

In Thoms the Second Circuit applied the Gunn holding to a case in which three judges, convened to consider a request for both injunctive and declaratory relief from the enforcement of Connecticut's flag desecration statute, entered a final order declaring that the statute was unconstitutional, but decided to forbear from the issuance of an injunction. The court of appeals held it had jurisdiction to hear the appeal from the grant of only declaratory relief.

In both Gunn and Thoms those appealing the orders of the three-judge courts were state defendants, so that even if those orders were construed as denying injunctions, the appealing parties would have no right to direct Supreme Court review. Gunn v. University Comm., supra at 390 n.5.

27415 U.S. 452 (1974).

${ }^{28} I d$. at 456 .

${ }^{29}$ Becker v. Thompson, 459 F.2d 919, 921 (5th Cir. 1972), rev'd on other grounds sub nom. Steffel v. Thompson, 415 U.S. 452 (1974).

${ }^{30} 415$ U.S. at 457 n.7. "Younger-Samuels principles" are those controlling the jurisdiction of a federal court to interfere with state criminal prosecutions. Younger v. Harris, 401 U.S. 37 (1971); Samuels v. Mackell, 401 U.S. 66 (1971). The requirement that a dismissal under these principles can only be made by three judges may have been superseded by MTM, Inc. v. Baxley, 420 U.S. 799 (1975). See notes 58-63 infra \& accompanying text. 
The Supreme Court gave no further reason for holding that the court of appeals had jurisdiction. In order to reach the Steffel result, however, the Court must have been saying that the court of appeals had jurisdiction over this appeal of the denial of declaratory relief alone because a single judge (whose decision would be appealable only to that court) would have had jurisdiction over a claim for declaratory relief alone. The court of appeals in Stone thought that its decision followed naturally from Steffel:

If a court of appeals has jurisdiction in a case where a single judge has taken action that could properly be taken only by three judges, provided that the appellant limits himself to action which the single judge could properly have taken, it would seem to follow a fortiori that the court of appeals has jurisdiction when a single judge has only taken action he could properly take, even though he was asked to take action he could not properly take and made no disposition of the request to do more. ${ }^{31}$

Yet Steffel does not dictate the result reached in Stone. The peculiar fact situation of Steffel, in which plaintiff abandoned his claim for injunctive relief, makes the case similar to Mendoza-Martinez in that it can be treated as if the plaintiff sought only declaratory relief from the beginning. If the case is viewed in retrospect in that posture, the single judge could "properly" have taken action on the only element remaining in the case. Under this view Steffel was a case in which lower court jurisdiction was "patched up" in retrospect.

Viewing the case differently, Judge Friendly perhaps thought that Stone followed a fortiori from Steffel because he believes jurisdiction cannot be patched up retrospectively: traditionally an appellate court has no jurisdiction over the merits of an appeal from a court with no jurisdiction. ${ }^{32}$ Under this view, for Steffel to have been decided on the merits, the single judge must have had jurisdiction to deny declaratory relief while the request for an injunction was pending. If no distinction exists

${ }^{31} 528$ F.2d at 1089 (footnote omitted).

32 E.g., Mitchell v. Maurer, 293 U.S. 237, 244 (1934) ("An appellate federal court must satisfy itself not only of its own jurisdiction, but also of that of the lower courts in a cause under review." (footnote omitted)); Becker Transp. Co. v. Department of Pub. Util., 314 Mass. 522, 527, 50 N.E.2d 817, 820 (1943) (labeling this proposition "elementary"). 
between grants and denials of relief in three-judge law, ${ }^{33}$ the single judge in Stone must have had power to grant declaratory relief as well. ${ }^{34}$

If one accepts the premise that in rare cases jurisdiction can be patched up, however, two possible ways of distinguishing Steffel from Stone emerge. The first is to say that Steffel-patching did not occur in Stone because at all relevant times plaintiff Stone, unlike Steffel, sought injunctive as well as declaratory relief; that he did not seek injunctive relief on appeal is irrelevant, because he was appellee, and did not seek anything. When Steffel reached the court of appeals, only a suit for declaratory relief remained; in Stone, even in retrospect, a suit remained for both declaratory and injunctive relief over which a single judge would not have had jurisdiction. ${ }^{35}$ Second, even if Steffelpatching theoretically could have been employed in Stone, it should not have been, because it would have paved the way for judicial subversion of the three-judge court statutes. ${ }^{36}$

Once Steffel is thus distinguished from Stone, it is seen that to assume that the single judge could "properly" grant declaratory relief when also faced with a claim for injunctive relief, just because he could act if faced with a request for declaratory relief alone, is to assume away the primary issue of Stone: whether a single judge currently faced with a claim for injunctive relief lacks jurisdiction to grant declaratory relief.

\section{B. Single Judge's Ability to Avoid Three-Judge}

Requirement by Granting Declaratory Relief

The holding in Mendoza-Martine ${ }^{37}$ that suits requesting only declaratory relief do not require three judges or direct review represents, as the court in Stone emphasizes, the principal step in the "significant subversion" of the policy of the three-judge statutes to protect states from the improvident actions of single judges. One possible reading of Stone, however, would extend

${ }^{33}$ See Ex parte Metropolitan Water Co., 220 U.S. 539 (1911).

${ }^{34}$ This would be true even if one of the parties had requested a three-judge court. The court in Stone, however, indicated that its holding might not extend to a case in which "state defendants made a timely request for a three-judge court." 528 F.2d at 1090. For a discussion of the court's view of the effect of a timely request for a threejudge court, see notes 39-47 infra \& accompanying text.

${ }^{35}$ After the Second Circuit reverses and remands, Stone's surviving complaint presumably asks for both injunctive and declaratory relief.

${ }^{36}$ Notes 37-47 infra \& accompanying text.

${ }^{37} 372$ U.S. 144 (1963); see Rockefeller v. Catholic Medical Center, 397 U.S. 820 (1970). 
the subversion significantly further by allowing not only the plaintiff, but also the single judge, to control his jurisdiction to hear the case: if a timely request for a three-judge court by defendants would not have deprived the single judge of jurisdiction to order declaratory relief for Stone, then the single judge may control his own jurisdiction by entering a declaratory judgment rather than an injunction. This also differentiates Stone from the earlier cases in which a three-judge district court determined merely the course of appellate review by acting only on the request for declaratory relief; in those cases three judges rather than one made the original determination of the statute's validity, as the statutory policy requires. What makes the elimination of the intended protection to the state particularly significant is that the holding in Stone would only apply in cases where the state lost, because a decision denying the plaintiff declaratory relief would also deny him injunctive relief, and thus could only be made by a three-judge court.

The policy of protecting the state against single-judge decisions may already have been weakened by Hagans $v$. Lavine. ${ }^{38}$ In Hagans the Court held that when a single judge is faced with a claim for injunctive relief on both statutory and constitutional grounds, he may avoid, by deciding against the state only on the nonconstitutional question, both the constitutional issue and the necessity for convening a three-judge court. On the other hand, the Stone approach set out above allows a single judge at his discretion to make a ruling against the state on constitutional grounds without calling a three-judge court.

That the court in Stone recognized the jurisdictional difficulties of the single judge's acting in this way is indicated by its observation that it was "not here dealing with a case where state defendants made a timely request for a three-judge court." ${ }^{39}$ Raising the issue of the "timeliness" of the request suggests that the three-judge requirement might be waivable. The court supported this interpretation of the statute by indicating that whether either party asked for a three-judge court is significant in deciding whether the district judge had power to hear the case: "It is plain enough that if either party had requested the convening of a three-judge court, the request should have been granted."40

38415 U.S. 528 (1974); see Murrow v. Clifford, 502 F.2d 1066 (3d Cir. 1974).

39528 F.2d at 1090 .

40 Id. at 1088. 
The court avoided specifying whether the single judge would have lost jurisdiction to enter his order for solely declaratory relief if a timely request for a court of three judges had been made. ${ }^{41}$ If so, the three-judge statutes are nonjurisdictional (waivable) to the extent that they protect the parties from single judge decisions on requests for declaratory relief appended to requests for injunctions. ${ }^{42}$ This waivability makes sense if no decisions granting only declaratory judgments are directly appealable to the Supreme Court regardless of the relief requested; ${ }^{43}$ if a case is not of a nature requiring direct review, the statutes do not indicate that it is of a nature requiring three judges. If Stone is read this way, then the parties, but not the single judge himself, can influence the decision whether or not to convene a three-judge court. This of course raises the possibility of a much broader waivability of these statutes. If neither party feels the need for the protection of three judges and of direct review, then the logic here would suggest that only one judge should be required. If we accept the view that the statutes were enacted to protect the states from single-judge action, then the states alone should be able to waive the protection. ${ }^{44}$ Either of these results would be a significant change from current procedures. ${ }^{45}$

If, however, a timely request for three judges would not have deprived the single judge of jurisdiction to enter declaratory relief, then the court is extending dramatically the possibilities for "subversion" 46 of the three-judge statutes by giving

${ }^{41} \mathrm{Id}$.

42 If this theory is true, the single judge obtained jurisdiction to enter declaratory relief by the parties' waiver of the three-judge provision.

43 Text accompanying notes 18-30 supra.

14 See, e.g., Offermann v. Nitkowski, 378 F.2d 22, 25 (2d Cir. 1967); AMERICAN LAw Institute, Study of the Division of JuRisdiction Between State and Federal Courts 331 (1969); Currie, supra note 3 , at 76-77.

${ }^{45}$ The language of the statute indicates that a single district judge must request a three-judge court on his own initiative, regardless of the requests of the parties. 28 U.S.C. $\$ \S 2281-82,2284(1)(1970)$. The decisions also indicate that (at least wherever there is a live request for an injunction) the statute is jurisdictional and nonwaivable. See Kennedy v. Mendoza-Martinez, 372 U.S. 144 (1963); Currie, supra note 3, at 76-77.

The suggestion of general waivability made in the text is of course a great extension of what Judge Friendly may be proposing in Stone, where he explicitly distinguished the case at bar, in which the district judge granted only declaratory relief, from "a case where injunctive relief had been granted [by one judge] after failure to ask for a three-judge court." 528 F.2d at 1090 (citing Crow v. California Dep't of Human Resources 325 F. Supp. 1314 (1970), rev'd, 490 F.2d 580 (9th Cir. 1973), vacated and renanded for consideration of mootness and if not moot for consideration of three-judge requirement, 120 U.S. 917 (1975)).

${ }^{46} 528$ F.2d at 1090 . 
the single judge power to avoid them at his discretion. ${ }^{47}$

Thus, both possible readings of Stone take it beyond existing precedent, but, depending on the reading, different groups may be expected to benefit. If the first reading is adopted, threejudge protection would remain available for those who want it, but litigants would gain some ability to dispense with it. The extent of this flexibility would depend on whether and how far Stone is extended. If the second reading is adopted, the single judge would gain a large measure of ability to control litigation at the expense of the wishes of a party desiring three-judge protection. This result may be acceptable to those who oppose the three-judge legislation in its entirety, but it contains obvious potential for abuse.

\section{When Is "Declaratory Relief" ONLY DeClaratory Relief?}

The declaratory relief granted in Stone produced the exact circumstances which the Supreme Court in MendozaMartinez-its only full consideration of the equivalence of injunctions and declaratory relief for purposes of the three-judge court statutes-indicated might dictate treating declaratory relief like an injunction. Because the single district court judge in Stone had granted class action status, the declaratory judgment was formally binding on Vermont for all recipients who, like Stone, received general assistance three or more times per month. In fact, the declaratory relief in Stone had precisely the same effect as an injunction against enforcement of the statewide regulations. As the court of appeals observed, "[I]n the absence of a stay, Vermont has been giving Goldberg-type hearings to persons within the class whose applications for continued assistance have been denied, with payments continuing pending the outcome of the hearing." 48

It can be argued that a declaratory judgment is always expected to have the same effect as an injunction and that other departments of government are expected to obey the "declaratory" mandates of the courts. For example, in Mendoza-Martinez ${ }^{\mathbf{4 9}}$ the government was not really "free" pending appeal to enforce the deportation statute which had been declared uncon-

${ }^{47}$ See note 36 supra \& accompanying text, on plaintiff's power to evade the threejudge requirement by asking for declaratory relief alone.

${ }^{48} 528$ F.2d at 1088.

49372 U.S. 144 (1963). 
stitutional. ${ }^{50}$ Even if this argument about the general nature of declaratory relief is rejected, the particular relief in Stone did, in the language of Mendoza-Martinez, "paralyze totally the operation of an entire regulatory scheme"51 throughout the state of Vermont. Although the order in Stone was in form declaratory rather than injunctive, it had the "injunctive" effect of requiring termination of a state's regulation (at least in the absence of a stay).

In deciding whether the single judge had jurisdiction, the Stone court should have considered the practical "injunctive" effect of the declaratory relief combined with the class action status granted plaintiff. Mendoza-Martinez emphasized the perceived "non-coercive" nature of the particular declaratory relief there granted, and strongly indicated that more coercive declaratory relief was to be treated differently. The Supreme Court's subsequent consideration of declaratory judgments in the context of three-judge court statutes has been quite summary, and, at least in Rockefeller, ${ }^{52}$ confused. ${ }^{53}$

\section{The ImPlications of $M T M, I_{N C .}$ V. $B A X L E Y^{54}$}

Part of the uncertainty surrounding Stone derives, as Judge Friendly noted, from a collateral source-the recent Supreme Court decisions reducing the number of cases that may be appealed directly to the Court under section 1253. Until the 1974 term of the Court, the settled view was that if a three-judge court was convened properly, then direct appeal to the Supreme Court was available from an order of that court granting or denying an injunction on any grounds. ${ }^{55}$ Then in Gonzalez v. Automatic Employees Credit Union ${ }^{56}$ the Supreme Court held that appeal from

${ }^{50}$ See D. Currie, Federal Courts 791 (2d ed. 1975); HĀrt and Wechsler, supra note 3, at 968. Mendoza-Martinez could almost certainly have obtained an injunction against enforcement of the statute, whether from a single-judge or a three-judge court, on the basis of the declaratory judgment. It is possible others may have been able to do so as well.

51372 U.S. at 154.

52 Rockefeller v. Catholic Medical Center, 397 U.'S. 820 (1970).

${ }^{53}$ See Mitchell v. Donovan, 398 U.S. 427, $432-33$ (1970) (Douglas, J., dissenting). But cf. id. at 429-30 (per curiam). The Court in Mitchell made no distinctions among kinds of declaratory judgments in relying on Mendoza-Martinez, perhaps because the Court was not reviewing an order granting declaratory relief whose coercive nature it could examine. Instead the lower court had denied relief.

54420 U.S. 799 (1975).

${ }^{55}$ See Note, The Three-Judge District Court: Scope and Procedures Under Section 2281, 77 Harv. L. Rev. 299, 311 (1963); $f f$. Florida Lime \& Avocado Growers, Inc. v. Jacobsen, 362 U.S. 73 (1960).

${ }^{36} 419$ U.S. $90,94-101$ (1974). 
the denial of an injunction for lack of standing lay in the court of appeals and not in the Supreme Court under section 1253, on the ground that only an order denying an injunction "required . . . to be heard and determined by a district court of three judges" was within the statute. An order denying an injunction that a single judge could enter, such as dismissal for lack of standing, was outside the direct appeal statute. ${ }^{57}$

Later in the term in MTM, Inc. v. Baxley, ${ }^{58}$ in which a threejudge court issued an order denying an injunction and dismissing the claim under Younger $v$. Harris ${ }^{59}$ because of a pending state criminal prosecution, the Court, dismissing plaintiff's appeal for lack of jurisdiction, held that section 1253 permitted direct appeal only from three-judge decisions that reached the question of the constitutionality of the challenged statute. ${ }^{60}$

In MTM, however, the Court declined to decide whether three judges were required to dismiss a case under Younger, ${ }^{61}$ thus leaving $M T M$ open to two possible interpretations. First, all decisions short of rulings on the constitutionality of the statute or regulation can be made by a single judge, and, as in Gonzalez, decisions that can be made by one judge are appealable to the court of appeals even if they are made by three judges; or second, some decisions that can be made only by three judges can be appealed only to the court of appeals.

Justice White's concurring opinion in MTM stated that the decision was viable only under the first interpretation. First, he argued, all orders required to be entered by three judges were explicitly within the language of section 1253 providing for direct appeal, and therefore only orders that one judge could

${ }^{57}$ Gonzalez did not reach the issue whether a decision based on the constitutional merits of the case is necessary to confer jurisdiction on the Supreme Court under $\S 1253$. That question was answered affirmatively in MTM, Inc. v. Baxley, 420 U.S. 799 (1975). Thus Gonzalez no longer has independent effect on the $\$ 1253$ issue. See notes 58-60 infra \& accompanying text.

${ }^{58} 420$ U.S. 799 (1975).

59 401 U.S. 37 (1971).

${ }^{60} 420$ U.S. at 804 . The interpretation of $\S 1253$ in $M T M$ still would further the primary congressional policy of providing for immediate Supreme Court review whenever injunctive relief against the operation of a statute or regulation was granted on constitutional grounds because in all such cases the lower court would reach the question of the statute's or regulation's constitutionality. Id. at 803-04, (citing Gonzalez v. Automatic Employees Credit Union, 419 U.S. 90, 98-99 (1974)). Note that for these purposes, "constitutional grounds" do not include the supremacy clause. See Swift \& Co. v. Wickham, 382 U.S. 111 (1965) (holding that where supremacy clause is the basis of the only substantial constitutional challenge in a case, no three-judge court need be convened, and appeal lies in the court of appeals).

61420 U.S. at 802 n.7. 
enter were outside the terms of the statute. If a dismissal ordered on any grounds but the constitutional merits of the case must be appealed to the circuit court, it must be outside the scope of section 1253, and therefore may be ordered by a single judge. ${ }^{62}$ Second, an appellate procedure that required a threejudge court of appeals to review a three-judge district court's decision was an "exorbitant expenditure of judicial manpower." 63

In Stone the court's holding would be supported most directly by the first interpretation of $M T M$, adopted by Justice White. Under this view a single judge faced with a claim for injunctive relief on constitutional grounds can still dispose of the case on any other claim or any other grounds available. If an order granting declaratory relief can be appealed to the court of appeals, then a fortiori a single judge could grant such relief as long as he did not reach the constitutionality of the challenged statute in an order granting an injunction. ${ }^{64}$ If, however, singlejudge jurisdiction and lack of direct appealability are not congruent, as under the second interpretation of $M T M$, then whether a single judge has jurisdiction when a plaintiff requests both injunctive and declaratory relief remains an open question to be decided under Mendoza-Martinez ${ }^{65}$ and Steffel. ${ }^{66}$

Judge Friendly's opinion in Stone, however, is also consistent with the second reading of MTM because he considers the result "clear enough" on the basis of the argument previously outlined under Mendoza-Martinez and Steffel. ${ }^{67}$ The terms of the order of the court of appeals to the single judge to abstain on remand, however, provide some evidence that Judge Friendly prefers the first interpretation, and that Mendoza-Martinez and MTM would allow a single judge to grant declaratory relief even when faced

${ }^{62} I d$. at 805 (White, J., concurring).

${ }^{63}$ Id. at 806-07 (White, J., concurring). Of course, given the structure Justice White proposes, three-judge courts will often make decisions that a single judge could have made, and judicial manpower will still be wasted.

${ }_{64}$ This conclusion requires the assumption that a plaintiff will not appeal the denial of injunctive relief if he receives declaratory relief. See Gunn v. University Comm., 399 U.S. 383,390 n.6 (1970).

65372 U.S. 144 (1963).

${ }^{66} 415$ U.S. 452 (1974).

${ }^{67}$ Just where all this, and the still more recent decision in MTM, Inc. v. Baxley

... leave traditional notions that under the three-judge statute the power of an appellate court to consider a case on the merits depends on what kind of court should have been convened below is a new puzzlement in this nevernever land, as Mr. Justice White pointed out in his concurrence in the case last cited ... . However, the conclusion for this case seems clear enough.

528 F.2d at 1090 (footnote omitted). See notes 18-31 supra \& accompanying text. 
with a claim for injunctive relief. The court issues the order to abstain without discussing whether abstention by one judge or three is required. Unless $M T M$ overruled the precedent that a single judge lacks power to abstain, however, only a three-judge court would have jurisdiction to abstain because plaintiff Stone still requested injunctive relief. ${ }^{68}$ Therefore, the proper order of the remand would have been that the single judge request that a three-judge court be convened, and that the three-judge panel abstain. If, however, $M T M$ gives a single judge jurisdiction to enter all orders except those adjudging the constitutionality of the challenged statute in granting or denying an injunction, then, as the court in its order in Stone seems to allow, the single judge has jurisdiction to abstain alone. ${ }^{69}$

\section{ConcLusion}

Starting with Kennedy $v$. Mendoza-Martinez, ${ }^{70}$ the courts, in differentiating declaratory from injunctive relief, have pursued a course which ultimately will bring them to the question whether granting declaratory relief on constitutional grounds when injunctive relief is also sought always has the same jurisdictional requirements as deciding on statutory or collateral grounds cases in which a plaintiff seeks injunctive relief on constitutional grounds.

The most persuasive argument against the Mendoza-Martinez doctrine is that, if the policy behind three-judge courts justifies maintaining them, then declaratory relief should always be treated like injunctive relief, at least in a "civilized society" in which government defendants are expected to obey the courts' declaratory mandates. ${ }^{71}$

${ }^{68}$ See Idlewild Bon Voyage Liquor Corp. v. Epstein, 370 U.S. 713, 715 (1962) (footnote omitted):

When an application for a statutory three-judge court is addressed to a district court, the court's inquiry is appropriately limited to determining whether the constitutional question raised is substantial, whether the complaint at least formally alleges a basis for equitable relief, and whether the case presented otherwise comes withın the requirements of the three-judge statute. Those criteria were assuredly met here, and the applicable jurisdictional statute therefore made it impermissible for a single judge to decide the merits of the case, either by granting or by witholding relief.

The single district judge in the court below had abstained without granting or denying the injunction.

${ }^{69}$ See MTM, Inc. v. Baxley, 420 U.S. 799, 805 (1975) (White, J., concurring). This reading would of course overrule Idlewild.

70372 U.S. 144 (1963).

${ }^{71}$ See note 50 supra \& accompanying text. 
In the absence of such a statutory scheme, or rather in the presence of a scheme which by judicial decision accepts Mendoza-Martinez, serious questions remain whether the declaratory relief exception should be wide enough to allow the single judge to avoid the three-judge statutes at his discretion, and whether all declaratory relief should be distinguished from injunctive relief. The opinion in Stone $v$. Philbrook is consistent with affirmative answers to both of these questions but unfortunately does not consider them fully. The court never questions, even given Mendoza-Martinez, which allows plaintiffs to manipulate the three-judge statutes, whether these statutes are not overly subverted by a system that allows a single judge who favors the plaintiff's position to avoid them. Further, the court in Stone never addresses the equivalence of injunctive relief and the "coercive" declaratory judgment issued by the single trial judge; in such a case even Mendoza-Martinez raises serious questions whether a single judge should act. Finally, the court indicates that $M T M$, Inc. v. Baxley ${ }^{72}$ holds the key to what a single judge may do, implying that he may do anything-including grant declaratory relief on constitutional grounds-short of issuing an order granting or denying an injunction which passes on the constitutionality of the challenged statute or regulation. If that interpretation of $M T M$ proves correct, then only overruling the Mendoza-Martinez-Rockefeller line of cases will prevent single judges from considering requests for declaratory judgments on constitutional grounds, even where the plaintiff also requests injunctive relief.

72420 U.S. 799 (1975). 